Ann. Biol. anim. Bioch. Biophys., 1979, 19 (1A), 45-54.

\title{
Morphological, biochemical and physiological studies on the preservation of buffalo (Bubalus bubalis) spermatozoa in different modified dilutors : Effects of chloroquine-diphosphate
}

\author{
par K. S. SIDHU *, S. S. GURAYA
}

\author{
Department of Zoology, College of Basic \\ Sciences \& Humanities, \\ Punjab Agricultural University, \\ Ludhiana (Punjab), India.
}

\begin{abstract}
Summary. A morphological, biochemical and physiological study has been made of the effects of chloroquine-diphosphate (a membrane stabilizer) on the preservation of buffalo spermatozoa in five modified dilutors designated here as $A_{1}, A_{2}, A_{3}, A_{4}$ and CAW. In almost all the five dilutors, there was significant $(p<0.01)$ progressive increase in the percentage of sperm abnormalities and the release of enzymes (hyaluronidase, glutamateoxaloacetic transaminase, alcohol, malate, lactate and sorbitol dehydrogenases) from spermatozoa into the media, and progressive decrease in the percentage of sperm motility and of the live sperms, with the increasing time of storage. Supplementation of these dilutors with $10^{-5} \mathrm{M}$ chloroquine-diphosphate significantly $(\mathrm{p}<0.01)$ lowered the percentage of sperm abnormalities and the release of various enzymes, and increased the percentages of sperm motility and of live sperm in most of the cases. Drug capacity varied in different dilutors. It was maximum in $A_{1}$ (egg yolk citrate, EYC) and minimum in citric acid whey (CAW).
\end{abstract}

\section{Introduction.}

Buffalo plays an important role in the dairy economy of Asia. Although in India itself it contributes more than 73.4 p. 100 of the total milk production, no suitable semen extender is yet available for this animal. The dilutors used for bull semen are not effective in the proper preservation of buffalo semen (Pavithran et al., 1972). This is apparently due to some compositional differences between bull and buffalo semen (Banerjee and Ganguli, 1971, 1973). The causes of ineffectiveness of various dilutors used for buffalo semen are not known. However, Guraya and Sidhu (1975a) reported that membranal lipid composition of buffalo spermatozoa differs from that of ram and bull spermatozoa. The membranes of buffalo spermatozoa are more permeable (Guraya and Sidhu, 1975b, 1976 ; Anand, 1976), and no attempt has been made previoulsy to stabilize them. Therefore, the present systematic study was undertaken to modify the five dilutors as well as to supplement them with a drug (chloroquinediphosphate) that is a known membrane stabilizer (Norman and Gombe, 1975). This

\footnotetext{
* Post doctoral Fellow CSIR, Gov't of India.
} 
study for the first time provides a more rational basis for effective preservation of buffalo semen and for conducting future fertility trials with the present modified dilutors.

\section{Material and methods.}

Semen samples (180 ejaculates) were collected regularly from five buffalo bulls with the help of artificial vaginae. Immediately after collection, semen samples were evaluated for volume, colour, density, mass motility, percentage motility, live/dead sperm count and total sperm count. They were then transported in Thermos flasks at $30^{\circ} \mathrm{C}$ to the laboratory and were diluted (dilution $1 \rightarrow 10$ ) in various diluents supplemented with $10^{-5} \mathrm{M}$ chloroquine-diphosphate (a membrane stabilizer used to decrease the release of enzymes from spermatozoa) and $50 \mu \mathrm{g} / \mathrm{ml}$ testosterone (to reduce the sperm metabolism enhanced by chloroquine-diphosphate).

\section{A. Preliminary trials.}

i) Effect of chloroquine-diphosphate and testosterone on fructolysis index. - The effect of different concentrations of chloroquine-diphosphate $\left(10^{-0.5}, 10^{-2}, 10^{-5} \mathrm{M}\right)$ and of testosterone $(25,50$ and $100 \mu \mathrm{g} / \mathrm{ml})$ on fructolysis index was studied according to the circular chromatographic technique of Sheth and Rao (1959).

ii) Effect of chloroquine-diphosphate and testosterone on percentages of sperm motility, sperm abnormalities and unstained sperm. - The method of Hancock (1952) was used to study sperm motility, abnormalities and live/dead count (unstained/stained sperm count).

From the results of preliminary trials a $10^{-5} \mathrm{M}$ concentration of chloroquinediphosphate and a $50 \mu \mathrm{g} / \mathrm{ml}$ concentration of testosterone were ultimately selected for main trials because the increase of the fructolysis index with the $10^{-5} \mathrm{M}$ drug was less than with the $10^{-0,5}$ and $10^{-2} \mathrm{M}$ concentrations. The $10^{-5} \mathrm{M}$ concentration also increased the percentage of motility, although it increased that of sperm abnormalities and decreased the percentage of live sperms more than the $10^{-2}$ and $10^{-0,5}$ concentrations. Similarly, the decrease in fructolysis index with the $50 \mu \mathrm{g} / \mathrm{ml}$ concentration of testosterone was intermediate between those caused by the 25 and $100 \mu \mathrm{g} / \mathrm{m} /$ concentrations.

TABLE 1

Composition of various dilutors modified (from Tomar and Desai, 1961)

\begin{tabular}{|c|c|c|c|c|c|c|c|}
\hline $\begin{array}{c}\text { Code } \\
\text { No. }\end{array}$ & $\begin{array}{c}\text { Sodium } \\
\text { citrate, } \\
2 \mathrm{H}_{2} \mathrm{O} \\
3 \text { p. } 100\end{array}$ & $\begin{array}{l}\text { Glycerol } \\
5 \text { p. } 100\end{array}$ & $\begin{array}{l}\text { Fructose } \\
5 \text { p. } 100\end{array}$ & $\begin{array}{l}\text { Glycine } \\
4 \text { p. } 100\end{array}$ & $\begin{array}{l}\text { Egg } \\
\text { yolk }\end{array}$ & $\begin{array}{l}\text { Glucose } \\
5 \text { p. } 100\end{array}$ & $\begin{array}{c}\text { Sodium } \\
\text { bicarbonate } \\
1.3 \text { p. } 100\end{array}$ \\
\hline $\begin{array}{l}A_{1} \ldots \ldots \ldots \\
A_{2} \ldots \ldots \cdots \\
A_{3} \ldots \ldots \cdots \\
A_{4} \ldots \ldots \ldots\end{array}$ & $\begin{array}{l}50 \\
50 \\
30 \\
-\end{array}$ & $\begin{array}{l}10 \\
30 \\
20 \\
-\end{array}$ & $\frac{-}{20}$ & $\begin{array}{l}\bar{z} \\
\bar{z}\end{array}$ & $\begin{array}{l}40 \\
20 \\
30 \\
66.8\end{array}$ & $\frac{-}{16.6}$ & $\frac{-}{\overline{16.6}}$ \\
\hline
\end{tabular}


The $50 \mu \mathrm{g} / \mathrm{ml}$ concentration of testosterone maintained a higher percentage of live sperm ; however, increased percentages of motility and of sperm abnormalities were not appreciably different from those with the 25 and $100 \mu \mathrm{g} / \mathrm{ml}$ concentrations.

The following dilutors modified from Tomar and Desai (1961), along with the CAW (Ganguli, Bhosrekar and Stephen, 1973) of the National Dairy Research Institute (NDRI), Karnal, India, were selected for screening (table 1).

Citric acid whey (CAW) was obtained from NDRI Karnal. Each packet was dissolved in $100 \mathrm{ml}$ of distilled water, mixed thoroughly and allowed to stand for $10 \mathrm{~min}$, then filtered through a cotton plug ; $\mathrm{pH}$ was adjusted to 6.8 with $10 \mathrm{p} .100$ sodium hydroxide.

Each dilutor was supplemented with penicillin $(10,000 \mathrm{IU} / 100 \mathrm{ml})$ and streptomycin $(0.1 \mathrm{~g} / 100 \mathrm{ml})$ to check bacterial growth during storage.

\section{B. Main trials.}

i) Dilution of semen samples in various dilutors. - Each semen sample $(2 \mathrm{ml})$ was divided into two halves, a control without chloroquine-diphosphate and an experimental with $10^{-5} \mathrm{M}$ chloroquine-diphosphate. Both the control and experimental samples were extended (Dilution $1 \rightarrow 10$ ) in the above-mentioned dilutors previously equilibrated at $37^{\circ} \mathrm{C}$ in separate graduated vials. Each vial was also supplemented with $50 \mu \mathrm{g} / \mathrm{ml}$ of testosterone. The samples in stoppered vials were stored in a refrigerator maintained at $4 \circ \mathrm{C}$.

ii) Enzyme release from spermatozoa and its subsequent control by chloroquinediphosphate in different dilutors. - The following enzymes were selected for study of their release in various dilutors at different time intervals : hyaluronidase, glutamateoxalo-acetic transaminase (GOT), alcohol dehydrogenase (ADH), malate dehydrogenase $(\mathrm{MDH})$, lactate dehydrogenase (LDH) and sorbitol dehydrogenase (SODH). The methods of their estimation have already been described (Sidhu and Guraya, 1978).

For the enzyme study, $2 \mathrm{ml}$ of diluted semen were drawn from both the control and experimental samples of each dilutor after different time intervals $(0,24,48$ and $72 \mathrm{hrs}$ ). Each sample was centrifuged at $5000 \mathrm{rpm}$ for $20 \mathrm{~min}$ at $10^{\circ} \mathrm{C}$. The supernatant was used for the estimation of enzymes. Control and experimental samples were compared for enzyme activity, and efficiency of the drug was evaluated.

iii) Percentages of unstained sperms, motility and abnormal spermatozoa. - The live/dead count, sperm abnormalities and sperm motility were studied according to the method of Hancock (1952) during the initial stage and after storage for 24, 48, 72 and $84 \mathrm{hrs}$ at $4^{\circ} \mathrm{C}$ in both the control and experimental samples.

\section{Results.}

\section{A. Preliminary trials.}

Effects of chloroquine-diphosphate and testosterone on fructolysis index and on percentages of unstained sperm, sperm abnormalities and motility in fresh buffalo semen. - Both chloroquine-diphosphate and testosterone in the various concentrations used affected 
the fructolysis index ( $\mathrm{mg}$ of fructose used per $\mathrm{hr}$ per $10^{\circ}$ sperms at $37^{\circ} \mathrm{C}$ ) and the percentages of unstained sperm, sperm abnormalities and motility.

Effects of chloroquine-diphosphate. - The various concentrations of chloroquinediphosphate increased the fructolysis index significantly $(p<0.01)$. The stimulation of fructolysis index diminished with decreasing concentrations of the drug used (table 2). The drug also increased the percentages of sperm motility and abnormalities and decreased significantly $(P<0.01)$ that of unstained sperm.

TABLE 2

Effects of chloroquine-diphosphate on fructolysis index and on percentages of motility, abnormalities and unsfained sperm in buffalo semen

\begin{tabular}{lccrc}
\hline $\begin{array}{c}\text { Concentration } \\
\text { of the drug (Molar) }\end{array}$ & $\begin{array}{c}\text { Fructolysis } \\
\text { index * }\end{array}$ & $\begin{array}{c}\text { Percentage } \\
\text { motility * }\end{array}$ & $\begin{array}{c}\text { Percentage } \\
\text { abnormalities * }\end{array}$ & $\begin{array}{c}\text { Percentage } \\
\text { unstained sperms * }\end{array}$ \\
\hline No drug (normal) $\ldots$ & $1.53 \pm 0.02$ & $55 \pm 2.73$ & $10.7 \pm 0.11$ & $60.0 \pm 2.17$ \\
$10^{-5} \ldots \ldots \ldots \ldots \ldots$ & $2.42 \pm 0.01$ & $70 \pm 1.71$ & $15.0 \pm 0.91$ & $50 \pm 0.97$ \\
$10^{-2} \ldots \ldots \ldots \ldots \ldots$ & $3.07 \pm 0.09$ & $68 \pm 2.07$ & $12.7 \pm 1.01$ & $52 \pm 1.01$ \\
$10^{-0.5} \ldots \ldots \ldots \ldots$ & $3.75 \pm 0.17$ & $60 \pm 1.71$ & $12 \pm 1.07$ & $55 \pm 1.87$ \\
\hline
\end{tabular}

* Means of five semen samples \pm SEM.

Effects of testosterone. - There was a significant $(p<0.01)$ progressive inhibition of the fructolysis index with increasing concentrations $(25,50,100 \mu \mathrm{g} / \mathrm{ml})$ of testosterone used (table 3 ). The percentage of motility was significantly $(P<0.01)$ reduced progressively with increasing concentrations of testosterone, as were those of unstained sperm and of total sperm abnormalities $(P<0.01)$.

\section{TABLE 3}

Effect of testosterone on fructolysis index and on the percentages of motility, abnormalities and unstained sperm in buffalo

\begin{tabular}{lcccc}
\hline $\begin{array}{c}\text { Concentrations } \\
\text { of testosterone } \\
(\mu \mathrm{g} / \mathrm{ml})\end{array}$ & $\begin{array}{c}\text { Fructolysis } \\
\text { index }\end{array}$ & $\begin{array}{c}\text { Percentage } \\
\text { motility }\end{array}$ & $\begin{array}{c}\text { Percentage } \\
\text { abnormalities * }\end{array}$ & $\begin{array}{c}\text { Percentage } \\
\text { unstained sperm * }\end{array}$ \\
\hline No steroid (normal). & $1.59 \pm 0.02$ & $70 \pm 2.51$ & $7.18 \pm 0.17$ & $76.5 \pm 2.11$ \\
$25 \quad \ldots \ldots \ldots \ldots \ldots \ldots$ & $1.27 \pm 0.02$ & $60 \pm 2.11$ & $5.12 \pm 0.18$ & $63.33 \pm 3.11$ \\
$50 \ldots \ldots \ldots \ldots \ldots$ & $1.02 \pm 0.01$ & $50 \pm 2.00$ & $6.75 \pm 1.81$ & $68.09 \pm 2.88$ \\
$100 \ldots \ldots \ldots \ldots \ldots$ & $0.57 \pm 0.01$ & $55 \pm 1.98$ & $4.15 \pm 0.66$ & $65.22 \pm 1.67$ \\
\hline
\end{tabular}

* Means of five semen samples \pm SEM.

B. Main trials.

Enzyme release from spermatozoa and its subsequent control by chloroquine-diphosphale after storage in various dilutors. - Five enzymes (hyaluronidase, GOT, ADH, 
MDH, LDH and SODH) were selected for study of their release and its subsequent control by chloroquine-diphosphate.

\section{TABLE 4}

Analysis of variance to test the capacity of the drug to decrease the release of various enzymes in different dilutors

\begin{tabular}{|c|c|c|c|c|c|c|}
\hline \multirow{2}{*}{ Source of variations } & \multicolumn{6}{|c|}{ «F » values for } \\
\hline & Hyaluronidase & GOT & $\mathrm{ADH}$ & $\mathrm{MDH}$ & $\mathbf{L D H}$ & SODH \\
\hline $\begin{array}{l}\text { Time } \ldots \ldots \ldots \ldots \ldots \\
\text { Dilutors } \ldots \ldots \ldots \ldots \ldots \\
\text { Drugs } \ldots \ldots \ldots \ldots \ldots \\
\text { Drug } \times \text { dilutors } \ldots \ldots\end{array}$ & $\begin{array}{l}3.12^{*} \\
5.92^{*} \\
0.75^{* * *} \\
1.40^{* * *}\end{array}$ & $\begin{array}{l}3.5^{* *} \\
3.57^{* *} \\
5.25^{*} \\
3.27^{* *}\end{array}$ & $\begin{array}{l}2.96^{* *} \\
10.13^{*} \\
29.24^{*} \\
20.23^{*}\end{array}$ & $\begin{array}{l}8.79 * \\
6.92^{*} \\
8.69 * \\
3.79 * *\end{array}$ & $\begin{array}{r}14.71 * \\
5.48^{*} \\
11.38^{*} \\
3.21 * *\end{array}$ & $\begin{array}{l}3.23^{*} \\
4.29 * * \\
3.71 * * \\
3.61 * *\end{array}$ \\
\hline
\end{tabular}

* Significant at 1 p. 100 level ; ** Significant at 5 p. 100 level ; *** Nonsignificant.

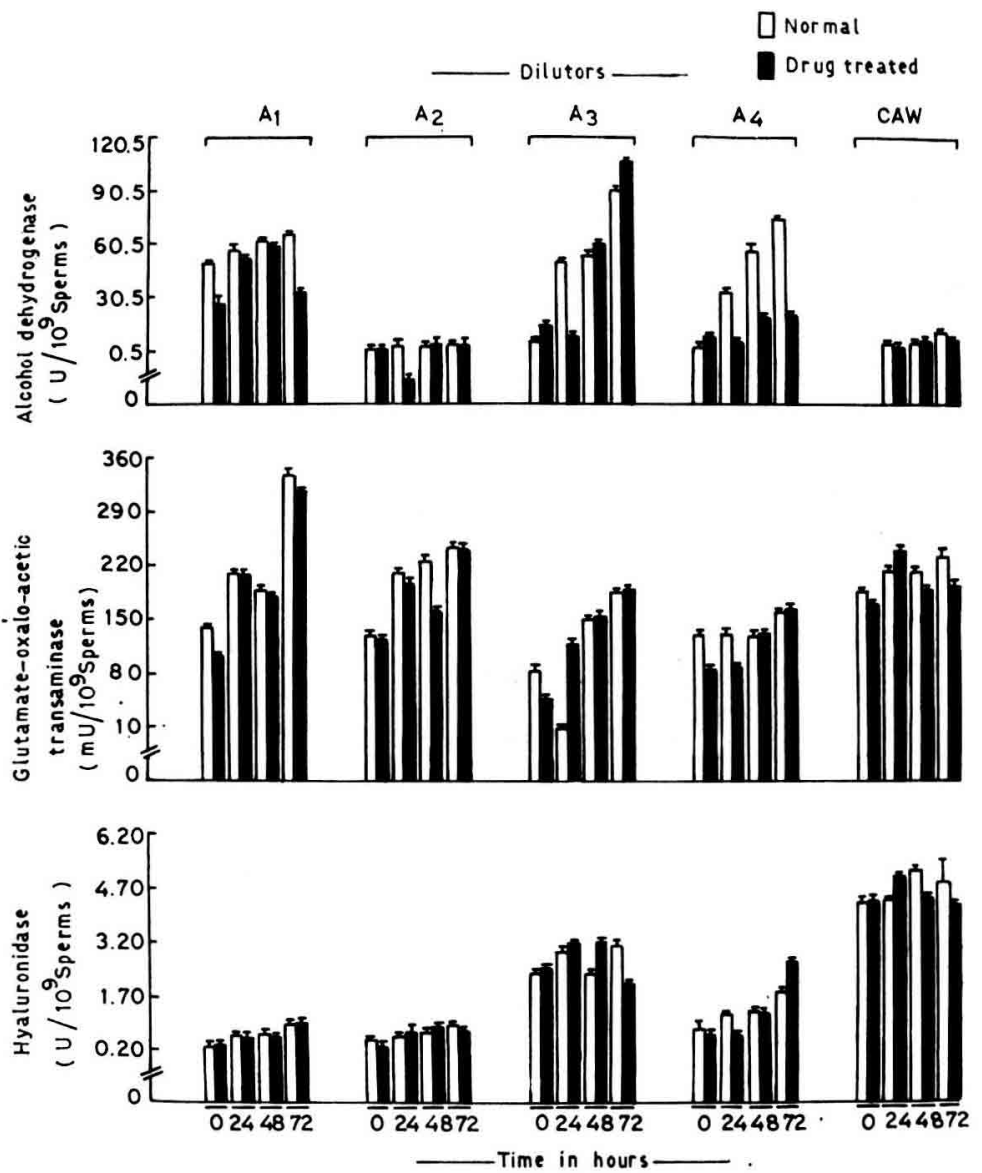

FIG. 1a. - Effect of chloroquine-diphosphate on the release of enzymes, viz., hyaluronidase, GOT, ADH in various dilutors at different time intervals of $4^{\circ} \mathrm{C}$. 
Normal samples. - There was a significant $(p<0.01)$ progressive release of various enzymes at different time intervals $\left(0-72 \mathrm{hr}\right.$ at $\left.4{ }^{\circ} \mathrm{C}\right)$ in almost all the five dilutors studied (see figs $1 a$ and $1 b$ ). The extent of the release varied significantly $(p<0.01)$ in different dilutors and at different time intervals (table 4).

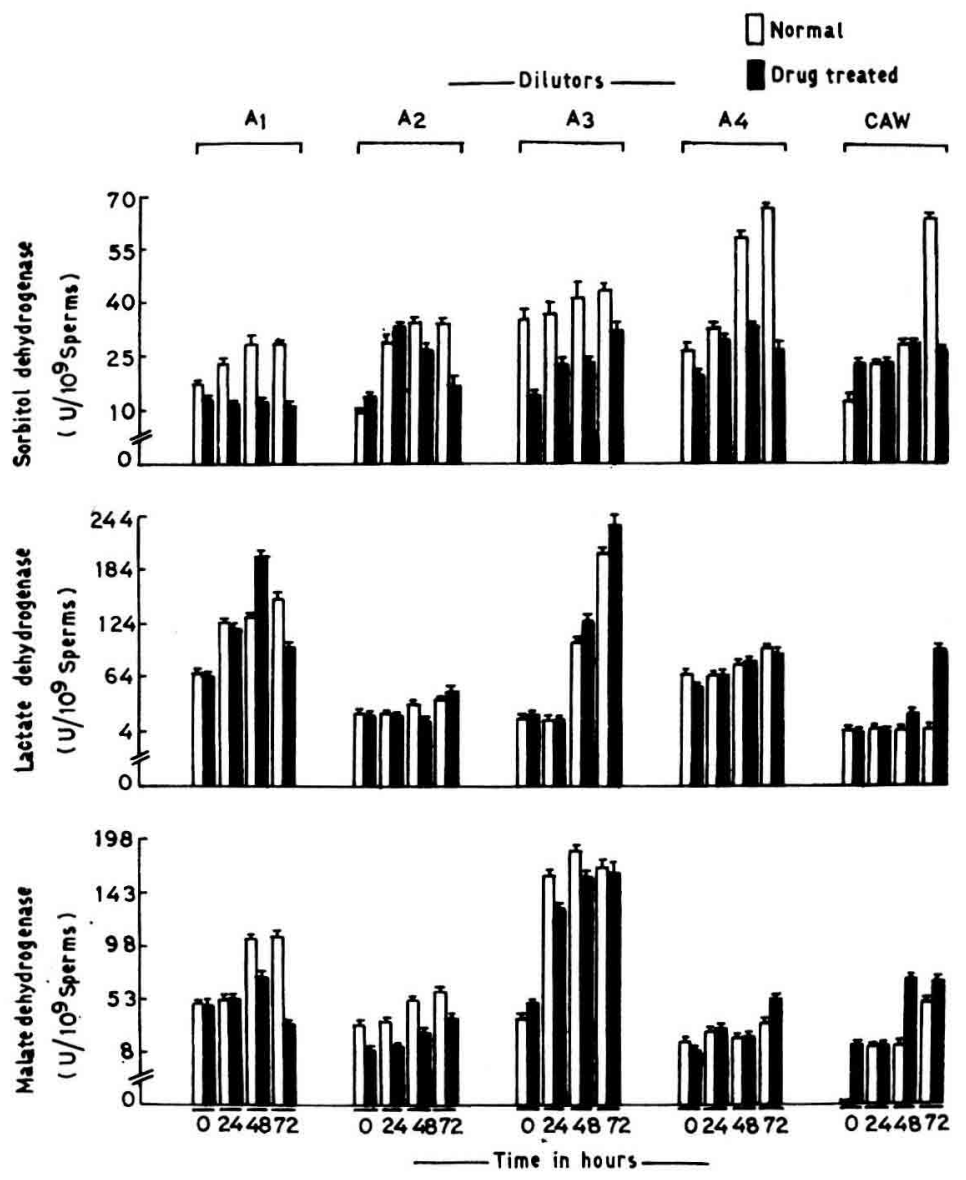

FIG. 1b. - Effect of chloroquine-diphosphate on the release of enzymes, viz., MDH, LDH, SODH in various dilutors at different time intervals at $4^{\circ} \mathrm{C}$.

Drug-treated samples. - Treatment of diluted samples with $10^{-5} \mathrm{M}$ chloroquinediphosphate under similar conditions could decrease the release of GOT, ADH, MDH, LDH and SOHD in most of the cases, whereas it could not decrease the release of hyaluronidase in different dilutors at different time intervals (figs $1 a, 1 b$ and table 4). The capacity of the drug, however, varied in different dilutors and at different time intervals; it was maximum in $A_{1}$ and minimum in CAW.

Semen siored at $4{ }^{\circ} \mathrm{C}$ in different dilutors with and without chloroquine-diphosphate. 
Effect of storage time on percentages of motility, unstained sperm and abnormalities. Effects of chloroquine-diphosphate on percentage of motility, unstained sperm and sperm abnormalities are given in figure 2.

Normal samples. - There was mostly a significant $(p<0.01)$ progressive decrease of the percentages of motility and unstained sperm and a progressive increase of that of sperm abnormalities in various dilutors at all time intervals (fig. 2). The extent of decrease in the percentages of motility and of unstained sperm and of the increase of that of sperm abnormalities varied significantly in different dilutors and at different time intervals.
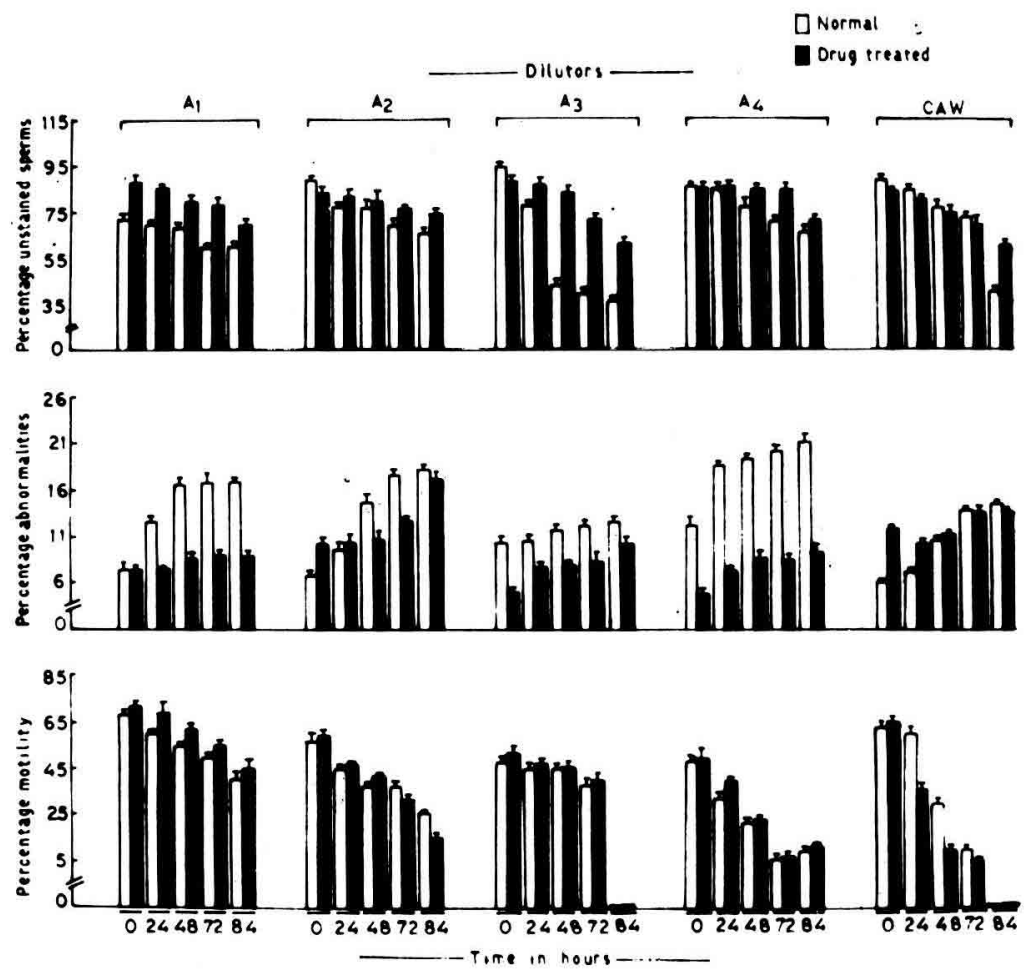

FIG. 2. - Effect of storage time af $4^{\circ} \mathrm{C}$ in different dilutors with and without chloroquine-diphosphate on motility rate, p. 100 unstained sperm and p. 100 abnormalities.

Drug treated samples. - Supplementation of diluted samples with $10^{-5} \mathrm{M}$ chloroquine-diphosphate in most of the cases increased the percentages of motility and of unstained sperm and decreased the percentage of sperm abnormalities significantly (fig. 2). The extent of increase or decrease varied significantly in different dilutors and at different time intervals. Drug capacity was maximum in dilutor $A_{1}$ and minimum in CAW. 


\section{Discussion.}

This study using various parameters of semen evaluation, including the effects of chloroquine-diphosphate (used to decrease the release of various enzymes from spermatozoa) on these parameters, has clearly demonstrated that the present modified dilutors can be arranged $\left(A_{1}>A_{4}>A_{2}>A_{3}>C A W\right)$ in decreasing order of their suitability for the preservation of buffalo spermatozoa.

Significant progressive decrease of percentage motility occurs in various dilutors at all time intervals as also reported by other workers (Grewal, Acharya and Dillon, 1969 ; Ganguli et al., 1973 ; Mukherjee, 1976 ; Bhosrekar and Ganguli, 1976). Maximum percentage of motility was maintained in dilutor $A_{1}$; it was minimum in CAW at different time intervals as also observed by Srivastava (1975) and Mukherjee (1976).

Chloroquine-diphosphate used as a membrane stabilizer stimulated the percentage of motility in all dilutors except in CAW at all time intervals. The drug was most potent in dilutor $A_{1}$ and least in CAW at different time intervals.

Significant progressive decrease in the percentage of unstained sperms occurred in different dilutors at variable time intervals as also reported by previous workers (Gokhle, 1958 ; Roy, 1958 ; Bhattacharya, 1962 ; Pavithran et al., 1972 ; Ganguli ef al., 1973 ; Ganguli, 1974 ; Bhosrekar and Ganguli, 1976). This decrease was maximum in CAW and minimum in $\mathrm{A}_{4}$ (egg yolk, glucose sodium bicarbonate) as revealed in this study. Similarly, Singh and Tomar (1959) reported a minimum decrease in the percentage of unstained sperm in egg-yolk-glucose-sodium bicarbonate dilutor as compared to egg yolk citrate and egg yolk glycine media. Ganguli et al. (1973) reported a smaller decrease of this percentage in CAW than in other dilutors; this is in contrast to the present observations as well as to those of Mukherjee (1976).

The addition of chloroquine-diphosphate could maintain a higher percentage of unstained sperms in different dilutors at variable time intervals (fig. 2). The potency of the drug was maximum in $A_{4}$ and minimum in CAW.

The present study has mostly shown a significant progressive increase in the percentage of sperm abnormalities in different dilutors at different time intervals. This is also in agreement with the observations of other workers (Srivastava and Prabhu, 1956 ; Gokhle, 1958 ; Tomar and Desai, 1961 ; Bhattacharya, 1962 ; Ganguli ef al., 1973 ; Ganguli, 1974 ; Bhosrekar and Ganguli, 1976). Our work shows that the maximum increase in sperm abnormalities occurred in dilutor $A_{2}$ and was minimum in $A_{4}$ (fig. 2).

Supplementation of the diluted sample with chloroquine-diphosphate under similar conditions significantly reduced the percentage of sperm abnormalities in different dilutors at variable time intervals. Drug capacity was maximum in dilutor $A_{1}$ and minimum in CAW.

Enzymes were released progressively from spermatozoa in different dilutors with increasing times of storage (figs. $1 a$ and $1 b$ ). Diluting the semen sometimes causes «dilution effect » (Mann, 1964 ; Harrison and White, 1972), leading to the release of intracellular proteins and enzymes from spermatozoa ; this is possibly because dilufion causes damage and increases membrane permeability (Blackshaw and Salisbury, 1957 ; Hood, Foley and Martin, 1970 ; Darin-Bennett at al., 1973 ; Sidhu and Guraya, 
1978). The release of various enzymes from buffalo spermatozoa may possibly result from membrane damage due to dilution. The release of various enzymes is maximum in CAW and minimum in $A_{1}$, clearly indicating that $A_{1}$ could better protect the sperm membrane than CAW against dilution effect. The release of hyaluronidase is due to shedding of the spermatozoon acrosome (Hancock, 1952 ; lype, Abraham and Bhargava, 1963 ; Quinn, White and Cleland, 1969 ; Guraya and Sidhu, 1975, 1976).

Supplementation of diluted samples with chloroquine-diphosphate decreased the release of various enzymes except that of hyaluronidase. The drug was most potent in $A_{1}$ and least in CAW. Since chloroquine-diphosphate is known to stabilize the membranes (Norman and Gombe, 1975), its capacity to decrease the release of various enzymes from buffalo spermatozoa can also be attributed to its stabilizing effects on the membranes. From the present discussion, it is recommended to use dilutor $A_{1}$ (EYC) supplemented with chloroquine-diphosphate for effective preservation of buffalo semen.

Reçu en février 1978.

Accepté en septembre 1978.

Résumé. Nous avons fait une étude morphologique, biochimique et physiologique des effets de la chloroquine-diphosphate (stabilisateur de membrane) sur la conservation des spermatozoïdes de buffle. Pour les 5 dilueurs utilisés, nous trouvons une augmentation progressive du pourcentage de spermatozoïdes anormaux, de la libération dans le milieu des enzymes du spermatozoïde (hyaluronidase, oxalacétoglutamique transaminase, déshydrogénases alcoolique, malique, lactique et sorbitique), et une diminution progressive du pourcentage des spermatozoïdes mobiles et vivants, en fonction de l'augmentation de la durée de conservation. En ajoutant $10^{-5} \mathrm{M}$ de chloroquine-diphosphate aux dilueurs, on diminue significativement $(p<0,01)$ le pourcentage de spermatozoïdes anormaux ef la fuite des enzymes et on augmente le taux de spermatozoïdes mobiles et vivants, dans presque tous les cas. L'efficacité de la chloroquine varie selon les dilueurs, elle est maximum pour le dilueur jaune d'œuf-citrate et minimum pour le dilueur petit lait-acide citrique $(\mathrm{pH} \mathrm{6,8)}$.

\section{References}

ANAND S. R., 1976. Metabolic studies of buffalo semen. Ann. Prog. Report N. D. R. I. Karnal, India.

BANERJEE A. K., GANGULI N. C., 1971. Differentiation of semen from Bos bubalis and Bos taurus indicus by starch gel electrophoresis. J. Anim. Sci., 32, 1212-1216.

BANERJEE A. K., GANGULI N. C., 1973. Some aspects of the composition of buffalo semen. J. Reprod. Fert., 33, 171-173.

BHATTACHARYA P., 1962. Artificial insemination in water buffalo. In MAIDE J. P. The semen of animals and artificial insemination. Commonw. agric. Bur., England.

BHOSREKAR M., GANGUL! N. C., 1976. Preservation characteristics of buffalo semen in citric acid-whey as an extender. J. Reprod. Fert., 48, 215-216.

BLACKSHAW A.W., SALISBURY G.W., 1957. Factors influencing metabolic activity of bull spermatozoa. II. Cold shock and its prevention. J. Dairy Sci., 40, 1099-1106.

DARIN-BENNETT A., POULOS A.,WHITE I. G., 1973. A re-examination of the role of phospholipids as energy substrates during incubation of ram spermatozoa. J. Reprod. Fert., 34, 543-546.

GANGULI N. C., 1974. A breakthrough in artificial insemination of buffalo. Ind. Dairyman, 26, 243247.

GANGULI N. C., BHOSREKAR M., STEPHEN J., 1973. Milk whey as a diluent for buffalo semen. J. Reprod. Fert., 35, 355-358.

GOKHLE D. R., 1958. Glucose, sodium bicarbonate and sulphamezathine buffer as a diluent of buffalo semen. Ind. vet. J., 35, 573-581. 
GREWAL N. S., ACHARYA R. M., DHILLON J. S., 1969. Comparative efficiency of different diluents for preservation of bull and buffalo bull semen. Ind. vet. J., 46, 687-692.

GURAYA S. S., SIDHU K. S., 1975a. Correlative histochemical and biochemical study of lipids of buffalo spermatozoa. J. Reprod. Fert., 42, 373-376.

GURAYA S. S., SIDHU K. S., 1975b. Histochemical localization of hydrolytic enzymes in the buffalo spermatozoa. Acta histochem., 54, 307-312.

GURAYA S. S., SIDHU K. S., 1976. Morphological, histochemical and biochemical observations on the buffalo (Bos bubalis) spermatozoa. In : Proc. 8th int. Congr. anim. Reprod. A. I., Krakow, vol. I, 98 (abstr.).

HANCOCK J. L., 1952. Morphology of bull spermatozoa. J. exp. Biol., 29, 445-453.

HARRISON R. A. P., WHITE I. G., 1972. Glycolytic enzymes in the spermatozoc and cytoplasmic droplets of bull, boar and ram and their leakage after shock. J. Reprod. Fert., 30, 105-115.

HOOD R. D., FOLEY C.W., MASTIN T. G., 1970. Effects of cold shock, dilution, glycerol and dimethyl sulfoxide on cation concentration in porcine spermatozoa. J. Anim. Sci., 30, 91-94.

IYPE P. T., ABRAHAM J. A., BHARGAVA P. M., 1963. Further evidence for a positive role of acrosome in the uptake of labelled amino acid by bovine and avian spermatozoa. J. Reprod. Fert., $5,151-158$.

MANN T., 1964. Biochemistry of semen and of the male reproductive tract. Methuen and Co, London.

MUKHERJEE D. P., 1976. Basic research on physico-chemical and morphological aspects of buffalo semen vis-a-vis evolving an extender. Ann. Progr. Report, Coll. Vet. Sci. and A. H., India.

NORMAN C., GOMBE S., 1975. Stimulatory effect of the lysosomal stabilizer, chloroquine on the respiration and motility of fresh and aged bovine spermatozoa. J. Reprod. Fert., 44, 481-486.

PAVITHRAN K., VASANTH J. K., BHIM SENA RAO M., ANANTAKRISANA C. P., 1972. A method for deep freezing of buffalo semen. Ind. vet. J., 49, 1125-1132.

QUINN P. J.,WHITE I. G., CLELAND K.W., 1969. Chemical and ultrastructural changes in ram spermatozoa after washing, cold shock and freezing. J. Reprod. Ferf., 18, 209-220.

ROY A. 1958. In : Artificial insemination of farm animals. PERRY E. J. Oxford and IBH Publishing Co., New Delhi, India.

SHETH A. R., RAO S. S., 1959. Fructose and fructolysis in human semen determined by chromatography. Experientia, 15, 314-314.

SIDHU K. S., GURAYA S. S., 1978. Effect of cold shock on release of enzymes in buffalo spermatozoa. Ann. Biol. anim. Bioch. Biophys., 18, 283-286.

SINGH R. B., TOMAR N. S., 1959. Efficacy of dilutors for preserving buffalo bull semen. Proc. ind. Sci. Congr. Assoc. 46th Sess, 456-457.

SRIVASTAVA R. K., 1975. Physicochemical and metabolic studies in buffalo semen. Annu. Progr. Report, Coll. Vet. Sci and A. H., India.

SRIVASTAVA R. K., PRABHU S. S., 1956. Dilutors for buffalo semen. Curr. Sci., 25, 58-59.

TOMAR N. S., DESAI A. K., 1961. A comparative study of various dilutors for the preservation of buffalo semen at $5^{\circ}$ to $7^{\circ} \mathrm{C}$. I. Egg yolk, sodium citrate containing dilutors. Ind. J. Dairy Sci., 14, 51-66. 